\title{
Meme and cyber sexism: Habitus and symbolic violence of patriarchy on the Internet
}

\author{
Moh. Faiz Maulana ${ }^{1^{*}}$ \\ ${ }^{1}$ Department of Sociology, Universitas Nahdlatul Ulama Indonesia, Indonesia \\ *Corresponding author \\ E-mail address: faiz@unusia.ac.id \\ DOI: https://doi.org/10.21107/sml.v4i2.11899
}

\begin{tabular}{|c|c|}
\hline Article Info & A BStRACT \\
\hline $\begin{array}{l}\text { Keywords: } \\
\text { Cyber sexism } \\
\text { Domination } \\
\text { Patriarchy } \\
\text { Internet } \\
\text { Habitus }\end{array}$ & $\begin{array}{l}\text { This study examines the various sexist practices on the Internet called } \\
\text { cyber sexism. The Internet seems to become a new world for patriarchal } \\
\text { domination. The amount of content, comments, and memes circulating } \\
\text { on the Internet and social media, such as Instagram, Facebook, Twitter, } \\
\text { and WhatsApp harassing women, is proof of the patriarchal power on the } \\
\text { Internet. This study used a qualitative method with a feminist perspective, } \\
\text { collecting memes through Instagram, Facebook, Twitter, and WhatsApp. } \\
\text { The memes were then reviewed and interpreted to find their meaning. } \\
\text { Using Pierre Bourdieu's habitus theory and symbolic violence, memes were } \\
\text { analyzed to find the factors that cause sexism against women and the logical } \\
\text { link between sexist practices in the real world and cyber sexism on the } \\
\text { Internet. Results indicate that people's habitus about patriarchy has become } \\
\text { a mental structure of society that influences stereotyped behavior and gender } \\
\text { bias and plays an important role in sexism on the Internet. The Internet, as } \\
\text { an arena, has become the initial capital for men to dominate. Naming and } \\
\text { mentioning women in various memes are the forms of symbolic violence } \\
\text { against them that form new sexist habitus on the Internet. }\end{array}$ \\
\hline
\end{tabular}

Citation suggestion:

Maulana, M. F. (2021). Meme and cyber sexism: Habitus and symbolic violence of patriarchy on the Internet. Simulacra, 4(2), 215-228. https://doi.org/10.21107/sml.v4i2.11899

Received 15 September 2021; Received in revised form 13 October 2021; Accepted 18 October 2021; Published online 25 November 2021. 


\section{Introduction}

The Internet knows no boundaries of space and time. This sentence first emerged from Tim Berners-Lee, an inventor of the World Wide Web. Laurie Penny (2013) explained that the Internet must be a neutral place not insulated by social, cultural, gender, economic, and political structures. Anyone and anywhere has the right to use it to build new interactions or expand knowledge. Although the Internet knows no boundaries of space and time, it still provides 'boundaries' to its users. For example, anyone who wants to join social media such as Facebook, Twitter, or Instagram must register themselves by submitting several identities, including their gender identity (Tiidenberg \& van der Nagel, 2020).

The world of the Internet is also an arena for class interaction that dominates and is dominated. Bimber (2000) explained that the gap between men and women also occurs on the Internet due to socio-economic and gender backgrounds. Economic stability, skills, and expertise in using computers and gadgets are the capital for men to carry out their legitimacy efforts. Knowledge and mastery of text and image processing applications are more friendly to men because their creators are still being dominated by men (Bimber, 2000). Park (2020), in their study, also revealed that the massive language of violence against women on the Twitter application was also caused by male domination of technological knowledge.

The phenomenon of the Internet and the phenomenon of technology cannot be fully understood without reference to gender issues. The social construction theory of technology (social construction of technology) shows that technology is socially shaped in specific social contexts (Dixon et al., 2014, p. 2). In this case, in Royal (2008), MacDonald explains that gender discourse and stereotypes on the Internet are also identified in social contexts related to the dichotomy, namely public space and private space. People's perspectives are still influenced by gender role stereotypes, which place women in the domestic sphere and men in the public sphere. Van Zoonen, in Royal (2008), explains this relationship by looking at the relationship between feminist theory and information technology. She wrote that several publications identified women's exclusion in new technologies' invention, creation, and design. Ultimately, this situation causes the existence of sexist behavior and patriarchal dominance on the Internet.

This condition will undoubtedly harm women, both on the Internet and in the real world. The existence of women will always be considered as second sex (de Beauvoir, 1989). On the other hand, the domination of patriarchy will be strengthened by the occupation of this new world. In an interview on DW Indonesia, Katharine Jarmul (2018), an algorithm consultant from the United States, revealed that various internet algorithms used today are often gendered, biased, and sexist concerning female stereotypes. Algorithms profoundly influence how gender is shaped, processed, and recirculated in contemporary consumer culture. In the midst of a strengthening understanding of gender equality and justice, internet algorithms tend to strengthen dualism and the hierarchical position of gender. The Internet has redefined gender stereotypes and unequal understandings (Schroeder, 2021; Schroeder \& Borgerson, 2015).

Cyber research emphasizing gender has grown rapidly in the past three years, evidenced in part by the number of relevant studies appearing as dissertation abstracts. The study of Carstarphen and Lambiase (1998) suggests that gender barriers in cyberspace are erected, in part, by language and 
code issues and that the rhetoric of cyberspace is modelled on the power structures and hierarchies of the domination discourse. Similarly, in an ethnographic study, Cushing (1996) finds a lack of female voices and actors on the Internet and suggests that male rituals and linguistic patterns dominate. Furthermore, Schroeder (2021) explained that algorithms profoundly influence how gender is experienced, processed, and recirculated in contemporary consumer culture. Thus, while consumers and researchers embrace a broadening conception of gender, the online marketplace seems to be working to reinscribe stereotypical notions of gender.

These studies have proved that the changing times to a more modern world cannot let women become subjects for themselves. The domination and gender inequality experienced by women in the cyber world is strong proof of the domination of patriarchy. Sex, however, places more importance on status as the pivotal determinant of society's position. Being the dominant social group, men engage in behavior that creates hierarchical social structure domination of the patriarchal system. Therefore, social power is reflected in men's as a function of their ruling masculine status (Veevers \& Henley, 1979). Therefore, various sexist practices against women are often easy to find on the Internet in various forms: including memes.

Memes were first used by Richard Dawkins (2006) an ethologist, and evolutionary biologist. In his book The Selfish Gene, he defines memes as the ability to reproduce, process, and disseminate the information structure of genes in biology. Memes are replicators that can influence human evolution through variations and distinctions that affect human life habits.

In its development, the term meme is not only used in the field of biology. Memes are now more widely used as a term in human culture as carriers of traits, patterns, and ideas of a culture that ultimately change the habits of a generation (Finkelstein, 2008). In addition, memes can also be associated with infectious ideas or thoughts, ideas that spread by themselves, and cultural aspects that tend to be imitative, both ideas, behaviors, and physical objects (Hidayat \& Immerry, 2020).

As a cultural product, memes are a form of representation of the behavior of a social group. In addition, memes show the existence of a communication process both between group members (individuals) and between these social groups. The relationship between creators, readers, and the meme itself is complex as a form of visual communication. Memes that are generally in the form of text and images contain symbols that must be interpreted in the context of communication. Therefore, the reader's background knowledge is vital in understanding a meme's intent, purpose, and meaning.

A meme in the internet world is defined as the rapid spread of a particular idea or idea presented in the form of text or images (Williamson et al., 2012); groups of words, pictures, or a combination of both that repeatedly appear as messages (Cannizzaro, 2016). Blackmore (2008) explained that internet memes are related to ideas, perceptions, emotions, behaviors, and even everything that can create instant experiences. In Soha \& McDowell (2016), Shifman defines internet memes as digital devices that share a common character (form, content, attitude) consciously created, circulated, imitated, or transformed by many internet users. Likewise, Hidayat (2019) mentions that memes as a means of communication in the form of symbols that can be text or images to convey messages or ideas. However, unfortunately, the messages that appear in memes are often sexist and stereotype women. 
Various memes in text and images with the content of harassment against women can be easily found on the Internet. The domination of patriarchy, in fact, does occur in not only the real world but also the world of the Internet. This dominance effect ultimately leads us - consciously or not to become accustomed to these harassing memes. In fact, not a few internet users share and spread it in their acts of communication, as humor - sexist humor.

This situation shows how patriarchal dominance works on the Internet to produce sexism and even harassment of women. Seeing this phenomenon, Penny (2013) explained:

Is the Internet not for everyone? Not really. Not yet. It was for boys, and if you were not one, you had to pretend to be, or you would be dismissed. I am fine with people deciding individually that they do not want to identify as female on the Internet -in the same way, I am fine with people deciding not to wear a short skirt if they feel afraid or uncomfortable- but no one should tell you to do that, and imply that if you do not comply, you are somehow the one at fault (Penny, 2013, p. 7).

Therefore, it is important to know about the logic of the relationship between sexism in the real world and on the Internet. Sexist practices on the Internet through memes culminate the practice of patriarchal cultural domination in the real world. This study discusses several forms of harassment content against women in the form of internet memes. Indeed, memes are used as a means of legitimizing patriarchal power through symbolic forms of violence.

\section{Method}

This study used a qualitative method with a feminist perspective. The work process was done in two stages. First, the memes obtained were reviewed to grasp the meaning of the symbols found. This process was carried out to find practices that show sexism or content of harassment against women. Second, the memes obtained were then interpreted using Pierre Bourdieu's (Bourdieu, 2001; Uhlmann et al., 2002) symbolic violence and habitus theory.

The object in this study is memes contained on the Internet which is suspected of containing sexism and content of harassment against women. The memes were taken on Twitter posts, Instagram posts, Facebook posts, and WhatsApp conversations, and only memes which used a certain hashtag were collected. Researchers used hashtag sexism and meme sexism as keywords to collect data. As Bruns and Burgess (2012) and Yang (2016) stated, hashtags are important in classifying data in social media. Through hashtags, millions of social media users can connect to talk about the same topic, even if they do not know each other. The 15 memes collected were then sorted and selected based on their content according to the formal object of this research, namely sexism content. Due to sensitivity reasons, the reference to the source was the app name, not the account source.

The interpretation was carried out by taking into account the context surrounding the object of study. Objects were analyzed through a process of repeated observation and reading. This process was carried out to find symbols that show the content of harassment against women. The next process was an analysis based on Pierre Bourdieu's theoretical framework of symbolic violence. Memes are analyzed and interpreted to find the factors that cause the emergence of memes with sexist content against women and the logical link between sexist practices in the real world and cyber sexism on the Internet. 


\section{Results and Discussion}

\section{Patriarchal habitus, doxa on the internet}

Harassment of women today can not only happen in the real world. On the Internet, women are also often mistreated. Penny (2013) even believes that there is no good space for women, even the Internet, which offers freedom. Indeed, content on the Internet often produces symbolic violence through hateful words, images, and communications with racist or sexist backgrounds - cyber sexism (Heitmeyer et al., 2005). On the Internet, for example, we often find memes that harass women, such as Figure 1 below:

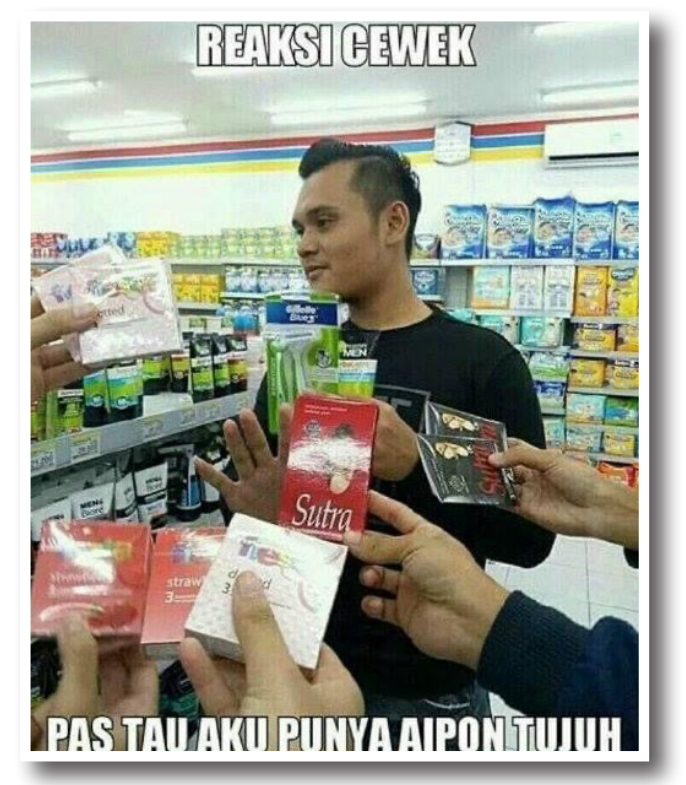

Figure 1. "Girls' Reaction" Source: Facebook

If we look at the meme's content in Figure 1, which features a man's face -also a representation of patriarchy- and the text: "Girls' reaction when she finds out I have an iPhone seven", and many condoms as answers the text. In this case, women have been assumed as creatures that can be easily exchanged with other things. This also shows the strong ideology that men have a higher position than women, and women are considered property of men. Whether we realize it or not, the use of these sentences and images has given rise to cyber sexism, exploitation, and abuse of women.

According to Bourdieu's (2001) symbolic violence framework, cyber sexism is an invisible violent behavior: "Symbolic power is that invisible power that can be exercised only with the complicity of those who do not want to know that they are subject to it or even that they exercise it" (Bourdieu, 2001, p. 164).

As stated by Bourdieu, cyber sexism is soft violence because it occurs when there is a relationship between people who do not want to know that they are the target, in the sense that the victim of cyber sexism does not realize that they are victims. In addition, cyber sexism in practice is also carried out repetitively in daily life on the Internet.

The strong domination of patriarchy in society is the root of sexism in the real world and on the Internet or cyber sexism. Patriarchy always views women as objects. Therefore, women often experience injustice, stereotypes, marginalization, or even violence and harassment. Society has adopted patriarchal norms in every aspect and has become a way of life. Therefore, the patriarchal system is constructed into something that seems natural and ordinary (Lerner in Rakoczy, 2004).

The domination of patriarchy, for Bourdieu, is the crystallization of Habitus. Habitus includes a person's knowledge and understanding of the world that makes its own contribution to the world's reality (Bourdieu, 2001). Habitus is a mental or cognitive structure that a person uses to deal with social life. Habitus describes a series of tendencies that encourage social actors or actors to act and react in certain ways (Ritzer \& Goodman, 2007).

Bourdieu explained that habitus results from historical and cultural creation (production) of individual (collective) 
practices in life that lasts for a relatively long historical period. As a product of history, Habitus creates individual and collective actions and therefore conforms to the pattern generated by history. Certain individual habits are obtained through life experiences and then internalized to use them to feel, understand, realize, and assess the social world (Dwizatmiko, 2010).

Bourdieu (2002) states the domination of men over women, in which social structures and structures of productive and reproductive activity exist based on sexual division that gives men the best part, which is confirmed in the schemes of the Habitus. Therefore, the domination of men over women is present as something that is understood as normal or doxa (Bourdieu, 2001). Society accepts it as something natural, as a dominant discourse. Doxa favors specific social arrangements in these domains, thereby privileging the dominant party and perceiving the dominant position as selfexisting. Therefore, it is not uncommon to find a treatment that dominates women in the real world and cyberspace (Internet).

In other memes, women are also treated as objects. We can see that in Figure 2:

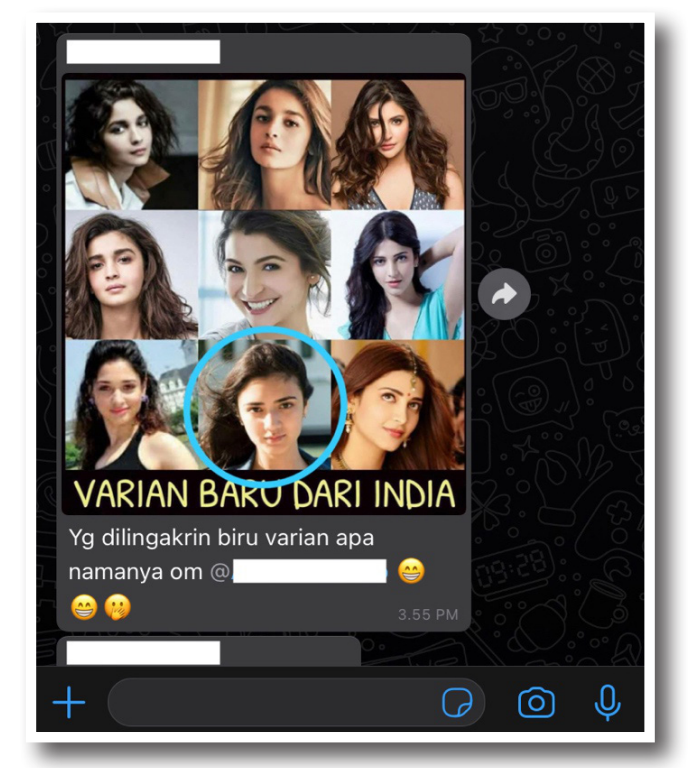

Figure 2. Sexist Conversation Source: WhatsApp
The memes feature a conversation in a WhatsApp group that several men had about the memes being shared. A sexist conversation ensued when one group member commented, "Which variant is circled in blue?" Then it ends with a laughing emoticon. This example is enough to illustrate how women are likened to an object that can be enjoyed with a choice of variants.

Mulvey in Durham (2006, pp. 87-104) explains that the existence of women is often to fulfil the instinct of scopophilia. It means that women are only used as objects of spectacle in various contents. The presence of women in the media, including memes, is often not appreciated as a subject, which also determines their own identity. They are considered more as a compliment, which is only seen from their physical existence alone, which shows how patriarchy works on the Internet to produce cyber sexism and even harassment of women.

Sexist memes containing symbolic violence occurs and is carried out on the Internet. Symbolic violence is an attempt to dominate one group over another. In this case, the domination of men over women. Women are objects of male domination through symbols that are used as a form of power practice.

Pierre Bourdieu (2020), in the framework of the theory of symbolic violence, mentions that four elements are commonly used in efforts to dominate power, namely Habitus, capital, arena, and symbolic violence. Habitus is a mental structure used to understand the social world, and this mental structure is the main product of the internalization of the structure of the social world. Capital is the ownership of materials, knowledge, skills, expertise, networks that can be used as a means of domination. The arena is the area or realm of domination actors. The climax is symbolic violence that is used as a means of legitimacy and domination. 
If it is associated with the meme phenomenon with the content of harassment against women, the efforts to legitimize and dominate men's power over women appear. Social construction, which can be referred to as Habitus, is the construction of women's function, role, and position in society.

Gender stereotypes and biases are essential factors in understanding these symbols of symbolic violence. In addition to physical and psychological characteristics, women are restrained by norms and values more than men. The traditional concept requires women to be gentle and obedient to men (Suryani, 2017). With the mental structure built, women unconsciously have accepted to be placed in a second-class social group under men. Knowledge instruments are a manifestation of the formation of domination relations. Symbolic violence is institutionalized through the mediation of an agreement that the dominant domination cannot carry out. Meanwhile, the dominant person has nothing except the knowledge instruments owned by the dominant (Musarrofa, 2019).

Therefore, cyber sexism is basically dominating a group over another in a different world from its origin. In this case, the dominance of men over women. Women are objects of male domination through symbols (memes) used as a form of power practice.

\section{Cyber sexism and evidence of patriarchal dominance}

Cyber sexism refers to sexist behavior, harassing, humiliating, oppressing, isolating individuals who cannot defend themselves or are dominated in the cyber world (Blaya, 2015). In addition, Couchot-Schiex \& Richard (2020) explained that cyber sexism refers to acts of violence that occur in cyberspace, are sexist, homophobic (lesbophobia), or sexual, and behaviors that reaffirm dominant gender norms as seen in Figure 3:

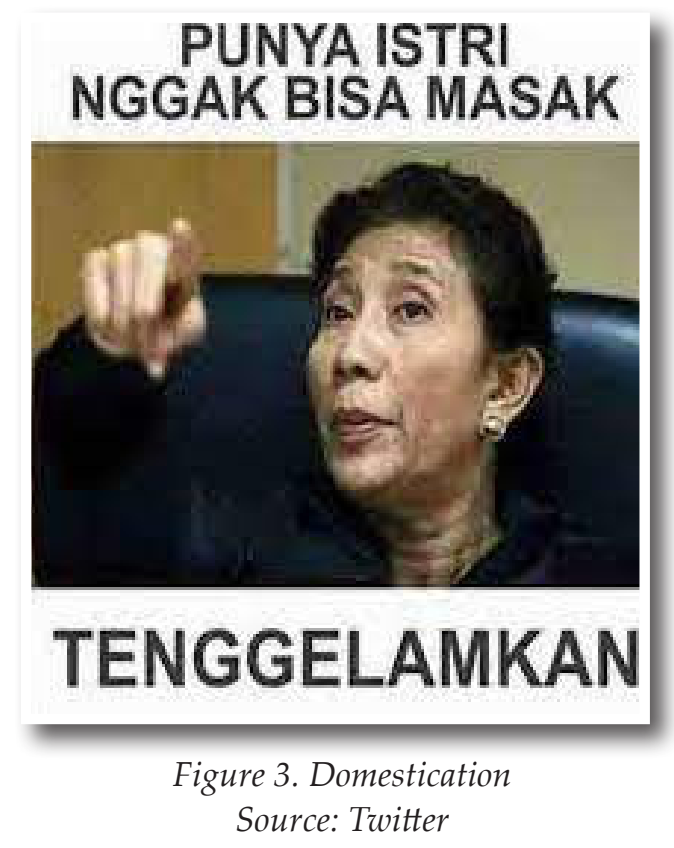

If we look at the contents of the meme in Figure 3, the text said, "Have a wife, cannot cook? Drown her!". In this case, women are considered domestic beings who must carry out domestic activities, such as cooking, washing, cleaning the house. This also shows the strong ideology that men have a higher position than women, and women are always subordinated to men. Whether we realize it or not, the use of these sentences and images has given birth to cyber sexism and the domestication of women.

Cyber sexism presents at least three characteristics: ease of anonymity, strong dissemination power, and difficulty controlling (Blaya, 2015). First, cyber sexism benefits from anonymity. Digital devices allow them to actunder cover of a falseidentity (pseudonym, identity theft) or anonymously (creation of ghost accounts). This condition has a major impact on both bullies and the bullied. Bullies can feel disinhibited due to their perceived impunity and not directly exposed to their actions' negative effects on the victims. The anonymity of sexist actors 
increases victims' insecurities (they do not know where the next attack will come from or who/how many people are targeting them) and a sense of alienation.

Second, the Internet allows for a strong dissemination power: cyber sexism can easily and rapidly reach many people in various networks. Whereas victims of 'traditional' (face-to-face) sexism were likely to find a safe haven, either at home or with a trusted group of friends, cyber sexism allows no respite to its victims. They are theoretically vulnerable to harassment 24 hours a day, with no guaranteed end in sight. In this context, a sole ill-intentioned message or picture disseminated without consent can generate repetitive and excessive harassment (Benbenishty \& Nir, 2015). Third of all, cyber sexism is challenging to control or halt. Disembodied, it escapes control from all involved, including authorities and repenting bullies who might wish to put an end to their victims' torments.

Penny (2013, p. 10) reveals that only a small proportion of Internet users do not harass women. Most of them will attack women for hatred or simply dislike seeing women in the midst of men's (public) world. There is a kind of assumption that if women do not want to be harassed, groomed, or "sexualized", then women should immediately go offline.

This situation certainly proves that patriarchal domination occurs not only in the real world but also on the Internet. Figure 4 presents an effort to objectify women:

If we look at the content of the meme in Figure 4 above, which features two girls, A (pious) and B (sexy), with the text: "Hey guys, which one do you choose?". In this case, women are only considered as objects. They are only seen as bodies that can be chosen to be owned and enjoyed by men.

These memes become an essential factor in understanding the behavior of cyber sexism as an attempt to dominate patriarchal

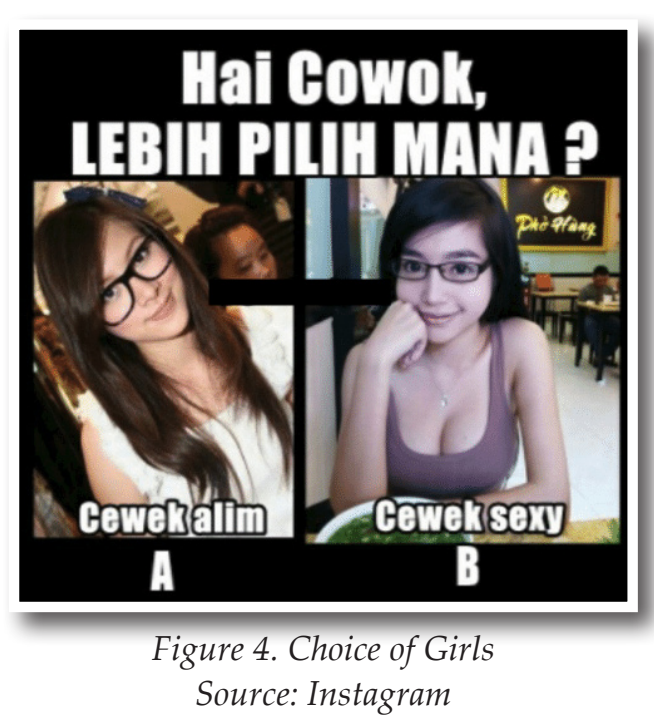

culture. The symbolic violence in memes has unconsciously placed women as objects and placed them in a weak position.

In addition, these memes have become an instrument of knowledge for women who create domination relations. Symbolic violence is institutionalized through sexist memes by men against women. Women as a dominant group have nothing but knowledge instruments which are also owned by men (Musarrofa, 2019).

Cyber sexism is also a vehicle for transmitting social norms inviting stereotypical performances of femininity and masculinity (Bailey, 2015). The few studies that have offered a gendered analysis of cyber sexism have highlighted the existence of powerful gender and sexual dynamics in the cyber exchanges. Cyber sexism reinforces stereotypical manifestations of gender. It simultaneously allows for the stigmatization of women (Ringrose et al., 2012, 2013).

This behavior is undoubtedly closely related to the patriarchal domination that surrounds the lives of most internet users. Patriarchy has become surveillance for all human life thousands of years ago, and now it has occupied a new space that should give freedom to everyone (Penny, 2013, p. 12).

Cyber sexism refers to acts that are directly or indirectly violent towards 
individuals, unfold over the Internet and face-to-face interactions, and aim to reiterate gender norms. These episodes result from internalized expectations regarding gender, gender expression, and sexual orientation. Cyber sexism operates continuously and manifests itself in varying severity, from creating sexist memes to objectifying women.

This cyber sexism behavior is an activity that influences each other from two different worlds; real and cyber. Cyber sexism results from the internalization of the socialization of dominant gender norms in the real world. Therefore, cyber sexism operates constantly. In addition, cyber sexism also results from efforts to maintain dominance in the real world into the internet world (CouchotSchiex \& Richard, 2020).

Therefore, cyber sexism and sexism are not two different practices. They are forms of the domination of patriarchy whose behavior can spread and change shape with each other. The behavior of cyber sexism and sexism goes back and forth between real and virtual spaces (Vandebosch \& Van Cleemput, 2008).

Thus, the Internet is not a separate, isolated, neutral space from the real world. Relationships that occur in the internet world are relationships that exist in the real world. Sexism in the internet world results from the culmination of patriarchal cultural behavior that dominates in the real world. The Internet is indirectly a vehicle for transmitting social norms that show dominance and display stereotypes of femininity and masculinity (Bailey, 2015). That is why we will find much sexist behavior on the Internet, as much as we find it in the real world.

\section{Patriarchy and the myth of virginity}

Cybersexist behaviors experienced by women on the Internet have illustrated how strong patriarchy's domination is on the Internet. For a long time, history and human civilization revolved around serving the male way of thinking (de Beauvoir, 1989). Women are always positioned as the second sex, which is given more restrictions in a patriarchal society. Social and other structures exist based on sexual divisions best for men (Bourdieu, 2001; de Beauvoir, 1989).

The patriarchal way of thinking is continuously produced and circulated in the real world and on the Internet. For Beauvoir (1989), this will result in a hegemonic way of thinking: women are always the other, second sex, and domestic.

One of the hegemonic ways of thinking created by patriarchal culture is the myth of virginity that continues to be produced, as seen in Figure 5:

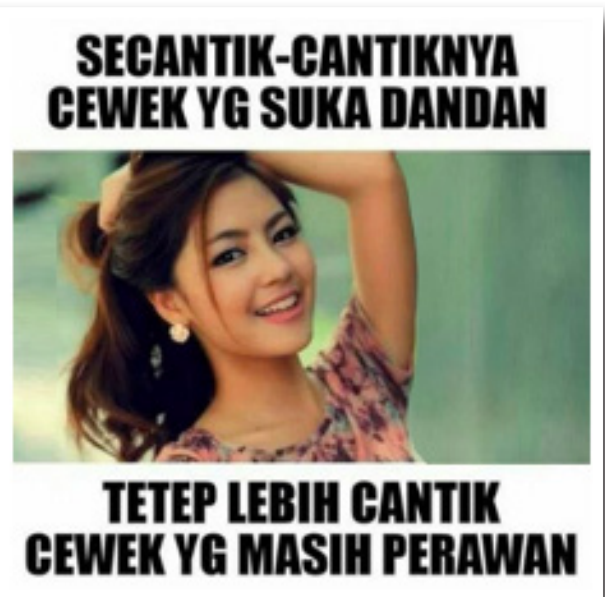

Figure 5. Virginity

Source: Instagram and Twitter 
The myth of virginity is produced with harassing memes content. If we look at the meme's content in Figure 5, we will find the behavior of cyber sexism. Memes featuring images of women with sexist texts read "You may be beautiful because you like to use makeup, but you will not be more beautiful than a virgin" and "Proud of being beautiful. Are you a virgin?" is proof that the myth about women is always produced. As if virginity is the substance of all definitions of women. Women will exist and, even further, will co-exist in society only when they are virgins. On the other hand, women will be considered freaks and immoral when they are not virgins anymore.

In Indonesia, for example, virginity is paramount because it is part of a woman's self-image. In addition, the demands in society for women's virginity before marriage make virginity one of the benchmarks for women: whether she is good or bad. Thus, if there is a gap between ideal expectations and existing self-realities, it will impact women's self-concept.

The ideal female self-concept is a culture formed by society. This culture is called objectification culture, which includes objectification practices such as commenting on the body, evaluating the body, and so on (Fredrickson \& Roberts, 1997). The process of internalizing the objectification culture is what makes individuals do selfobjectification (Ratih, 2015). Unfortunately, the practice of self-objectification in women is a subtle form of patriarchy and sexism.

McKay (2013) explained that three factors contribute significantly to the occurrence of self-objectification, including the influence of media, relationships, and societal influences. In this case, the influence of memes on the Internet like Figure 3 often normalizes and reinforces the sexualization and objectification of women.

However, often many women themselves accept such a situation as something that is taken for granted. Beauvoir describes it as myth: the false objectivity of the transcendent. In other words, all forms of discrimination have been mystified. It means that the oppressed do not feel oppressed and think that what is happening is natural and needs to be accepted by the situation (De Beauvoir, 1989).

Women and injustice seem to have a shackled relationship: they agree that all forms of repression against them are postulates established, when in fact, they never know that they are only following the false truth. The myths of virginity also continue to be accepted throughout history, even developing according to the times.

These things become a kind of guiding idea exploited by the people's mind machine as a way of life for women; those women are captives in chambers -bodies reduced to mere means of reproduction. So, what happens is the stigmatization that men are nobler than women. These myths are stored safely in people's memory sheets, protected by the arrogance of history and civilization into the subconscious so that women must be willing to accept that they are only the second set.

Men have always written history, just as his "his-story" skillfully plays essential roles in the historical stage, because the strong will be glorified, "prehistoric times when physical force was very important, those who are the strongest had all the right and power" (de Beauvoir, 1989). So, since the beginning, gender inequality has occurred, which places women in a marginal area. That is, women are stereotyped or placed in a passive and helpless position. The result is a civilization thick with sexism and discrimination in the real world and on the Internet.

That is how history and civilization are formed through human logic. The aim is to perpetuate the domination and arrogance of patriarchal power wherever it is located. In 
other words, whenever there is domination, there is always a motive for power.

\section{Conclusion}

Although the world has changed for the better and human civilization is progressing with the Internet, the fate of women seems to have stepped in the opposite direction, even worse. The phenomenon of cyber sexism on the Internet is proof of how the fate of women is determined.

The emergence of the Internet does not change anything about the condition of women. Stereotypes, domination and subordination remain intact attached to the female body. The world, for women, has not changed with the advent of the Internet. The domination of patriarchy still occupies the top of the mental structure of most people. Patriarchy is a habitus that is not easily lost or even forgotten. Its presence will continue to be reproduced in line with the development and progress of the times.

The many sexist memes are proof of the legitimacy of the patriarchal culture that positions women as objects. This behavior takes advantage of the socio-cultural mental structure that surrounds the lives of society. The concepts of sexism and gender become a means of strengthening male domination. Due to the development of a socio-cultural mental structure as Habitus in a very long time, women as victims do not realize and accept these forms of symbolic violence as normal.

Patriarchy has become a habitus (Bourdieu, 2001) in many different forms and places, real and virtual. The Internet has become a new world for the domination of patriarchy, perpetuating men's power over women. In the end, cyber sexism can be understood as a new way to control the dominance of certain genders virtually.

\section{Declaration of Ownership}

This article is my original work.

\section{Conflict of Interest}

There is no conflict of interest to declare in this article.

\section{Ethical Clearance}

This study was approved by the institution.

\section{References}

Bailey, J. (2015). A perfect storm: How the online environment, social norms, and law shape girls' lives. In EGirls, ECitizens. University of Ottawa Press.

Benbenishty, R., \& Nir, M. (2015). Harcèlement traditionnel et violence au moyen des outils électroniques de communication entre adolescents en milieu scolaire en Israël. Les Dossiers Des Sciences de l'éducation, 33, 13-30. https:// doi.org/10.4000/dse.772

Bimber, B. (2000). Measuring the gender gap on the internet. Social Science Quarterly, 81(3), 868-876. http://www.jstor.org/ stable/42864010

Blackmore, S. (1998). Imitation and the definition of a meme. Journal of Memetics: Evolutionary Models of Information Transmission, 2. http://jom-emit.cfpm. org/1998/vol2/balckmore_s.html

Blaya, C. (Ed.). (2015). Cyberviolence et école, Les Dossiers des Sciences de l'Éducation. Presses universitaires du Midi.

Bourdieu, P. (2001). Masculine domination. Stanford University Press.

Bourdieu, Pierre. (2013). Outline of a theory of practice. Cambridge University Press.

Bruns, A., \& Burgess, J. (2012). Researching news discussion on twitter. Journalism 
Studies, 13(5-6). https://doi.org/10.1080/1 461670X.2012.664428

Cannizzaro, S. (2016). Internet memes as internet signs: A semiotic view of digital culture. Sign Systems Studies, 44(4), 562-586. https://doi.org/10.12697/ SSS.2016.44.4.05

Carstarphen, M. G., \& Lambiase, J. J. (1998). Domination and democracy in cyberspace: Reports form the majority media and ethnic/gender margins. In Cyberghetto or cybertopia?: Race, class, and gender on the Internet. Bosah Ebo. ABC-CLIO.

Couchot-Schiex, S., \& Richard, G. (2020). Cybersexism: How gender and sexuality are at play in cyberspace. In Gender, sexuality and race in the digital age. D. Nicole Farris, et.al. Springer. https://doi. org/10.1007/978-3-030-29855-5_2

Cushing, P.J.(1996). Gendered conversational rituals on the internet: An effective voice is based on more than simply what one is saying. Anthropologica, 38(1), 47-80. https://doi.org/10.2307/25605819

Dawkins, R. (2006). The selfish gene: 30th anniversary edition -- with a new Introduction by the Richard Dawkins. Oxford University Press.

De Beauvoir, S. (1989). Second sex. Vintage Books.

Dixon, L. J., Correa, T., Straubhaar, J., Covarrubias, L., Graber, D., Spence, J., \& Rojas, V. (2014). Gendered space: The digital divide between male and female users in internet public access sites. Journal of Computer-Mediated Communication, 19(4), 991-1009. https:// doi.org/10.1111/jcc4.12088

Durham, M. G., \& Kellner, D. M. (2006). Media and cultural studies keyworks. WileyBlackwell.

Dwizatmiko. (2010). Kuasa simbolik menurut Pierre Bourdie: Telaah filosofis. Universitas Indonesia.
Finkelstein, R. (Ed.). (2008). A memetic copendium. Robotic Technology Inc.

Flew, T. (2007). New media: An introduction. Oxford University Press.

Fredrickson, B. L., \& Roberts, T. A. (1997). Objectification theory: Toward understanding women's lived experiences and mental health risks. Psychology of Women Quarterly, 21(2), 173-206. https://doi. org/10.1111/j.1471-6402.1997.tb00108.x

Heitmeyer, Wilhelm, \& Hagan, J. (2005). International handbook of violence research. Kluwer Academic.

Hidayat, H. N., \& Immerry, T. (2020). Pelecehan terhadap perempuan dalam meme. Kafa ah: Journal of Gender Studies, 10(2), 131-144. https://doi.org/10.15548/ jk.v10i2.330

Hidayat, H., Wasana, W., Pramono, P., Immerry, T., \& Dahlan, F. (2019). Folklore in meme: Minangkabau folklore survival form in the digital world. Proceedings of the Proceedings of the 2 nd International Conference on Local Wisdom, INCOLWIS 2019, August 29-30, 2019, Padang, West Sumatera, Indonesia. https://doi. org/10.4108/eai.29-8-2019.2288953

Jarmul, K. (2018). Algoritma internet bias gender dan seksisme. https://www.dw.com/id/ algoritma-internet-bias-gender-danseksisme/av-43865594

Lambrecht, A., \& Tucker, C. (2019). Algorithmic bias? An empirical study of apparent gender-based discrimination in the display of stem career ads. Management Science, 65(7), 2966-2981. https://doi.org/10.1287/mnsc.2018.3093

Mckay, T. (2013). Female self-objectification: Causes, consequences and prevention. McNair Scholars Research Journal, 6(1), 5370. http://commons.emich.edu/mcnair/ vol6/iss1/7 
Musarrofa, I. (2019). Pemikiran Pierre Bourdieu tentang dominasi maskulin dan sumbangannya bagi agenda pengarusutamaan gender di Indonesia. Kafa 'ah: Journal of Gender Studies, 9(1), 3449. https://doi.org/10.15548/jk.v9i1.227

Park, J. H., Shin, J., \& Fung, P. (2020). Reducing gender bias in abusive language detection. Proceedings of the 2018 Conference on Empirical Methods in Natural Language Processing, EMNLP 2018. https://doi.org/10.18653/v1/d181302

Penny, L. (2013). Cybersexism: Sex, gender and power on the internet. Bloomsbury Publishing.

Rakoczy, S. (2004). Religion and violence: The suffering of women. Agenda, 18(61), 2935. https://www.jstor.org/stable/4066596

Ratih, M. F. (2015). Hubungan antara kepercayaan diri dengan objektifikasi diri pada perempuan dewasa awal. Tesis. Universitas Sanata Dharma Yogyakarta.

Ringrose, J., Gill, R., Livingstone, S., \& Harvey, L. (2012). A qualitative study of children, young people and "sexting": A report prepared for the NSPCC. National Society for the Prevention of Cruelty to Children.

Ringrose, J., Harvey, L., Gill, R., \& Livingstone, S. (2013). Teen girls, sexual double standards and "sexting": Gendered value in digital image exchange. Feminist Theory, 14(3), 305-323. https://doi. org/10.1177/1464700113499853

Ritzer, G. (2014). Teori sosiologi modern. Kencana.

Royal, C. (2008). Framing the internet. Social Science Computer Review, 26(2), 152-169. https://doi. org/10.1177/0894439307307366

Schroeder, J.E. (2020). Reinscribing gender: Social media, algorithms, bias. Journal of Marketing Management, 37(3-4), 376-
378. $\quad$ https://doi.org/10.1080/026725 7X.2020.1832378

Schroeder, J. E., \& Borgerson, J. L. (2015). Critical visual analysis of gender: Reactions and reflections. Journal of Marketing Management, 31(15-16), 17231731. https://doi.org/10.1080/026725 7X.2015.1077883

Smith, G., \& Rustagi, I. (2021). When good algorithms go sexist: Why and how to advance a gender equity. Ssir.Org. https://ssir.org/ articles/entry/when_good_algorithms_ go_sexist_why_and_how_to_advance_ ai_gender_equity

Soha, M., \& McDowell, Z. J. (2016). Monetizing a meme: YouTube, Content ID, and the Harlem shake. Social Media + Society, 2(1), 1-12. https://doi. org/10.1177/2056305115623801

Suryani, E. (2017). Batari Hyang Janapati dalam perspektif gender. JENTERA: Jurnal Kajian Sastra, 6(2), 181-196. https:// doi.org/10.26499/jentera.v6i2.177

Tiidenberg, K., \& van der Nagel, E. (2020). Sex and social media. Emerald Publishing Limited.

Bourdieu, P. (2002). Masculine domination. Stanford Unviversity Press.

Vandebosch, H., \& Van Cleemput, K. (2008). Defining cyberbullying: A qualitative research into the perceptions of youngsters. Cyberpsychology and Behavior, 11(4), 499-503. https://doi.org/10.1089/ cpb.2007.0042

Veevers, J. E., \& Henley, N. M. (1979). Body politics: Power, sex, and nonverbal communication. Cambridge University Press.

Williamson, L. E. A., Sangster, S. L., \& Lawson, K. L. (2012). Hey girl ...": The effect of ryan gosling feminist memes on feminist identification and endorsement of feminist beliefs. Saskatoon. 
Yang, G. (2016). Narrative agency in hashtag activism: The case of \#blacklivesmatter. Media and Communication, 4(4), 13-17. https://doi.org/10.17645/mac.v4i4.692 